TECHNICAL TRANSACTIONS 4/2018

ARCHITECTURE AND URBAN PLANNING

DOI: $10.4467 / 2353737$ XCT.18.051.8363 SUBMISSION OF THE FINAL VERSION: $5 / 4 / 2018$

Marcin Charciarek (marcincharciarek@op.pl)

Institute of Architectural Design, Faculty of Architecture, Cracow a University of Technology

FORMS, DETAILS AND CONTEMPORARY MEANINGS

of Polish CONCRETE ARCHiteCTURe, PART 1

FORMY, DETALE I WSPÓŁCZESNE ZNACZENIA

POLSKIEJ ARCHITEKTURY BETONOWEJ, CZĘŚĆ 1

\begin{abstract}
The article is an attempt to show the relationship between architectural ideas and concrete matter in the implementation of Polish architecture of the beginning of the 21 st century. The first part shows examples in which the perfection of architecture is associated not only with the rational principles of 20th century architecture, but also with what we define as the search for aesthetics in appropriate expression of forms.
\end{abstract}

Keywords: concrete architecture, idea, matter, expressionisme

\title{
Streszczenie
}

Artykuł podejmuje próbę przedstawienia związku między ideami architektonicznymi a betonem jako materią w tworzeniu polskiej architektury na początku XXI wieku. Pierwsza część przedstawia przykłady, w których doskonałość architektury postrzegana jest nie tylko w odwolaniu do racjonalizmu architektury XX wieku, lecz także w związu z tym, co można by zdefiniować jako poszukiwanie estetyki w odpowiednich formach wyrazu. 


\section{Concrete architecture}

Concrete narrations in contemporary architecture are not explicit. It could be said that concrete and its forms cause extreme emotions and aesthetic reactions. Within one century, the myth of modern material, which helped to build a "new world", has been discredited by an image of something ugly, imperfect and boring. However, nowadays, this novelty and "nonexplicitness" have become one of the most significant features describing concrete. The mixture of water, cement and aggregate has become "the philosopher's stone", which can transform a murky mass into a material revealing further meanings and stylistic senses of architecture.

A fundamental metaphor of concrete is established and partly derives from the specifics of a visual code and its meanings - concrete imitates stone - it may have its optical, tactile and technical qualities. The unity of stone and concrete was defined at the beginning of the $20^{\text {th }}$ century by Auguste Perret, who was first to compare concrete to "a rejuvenated stone" [pierre rejeuni]. The metaphor was discovered and spread by Le Corbusier after building his Unite d'Habitation where concrete adopted the qualities of a natural rock. Le Corbusier claimed, "concrete is a recreated/reconstructed stone, worth exhibiting in its natural state". Another great modernist Louis Kahn, while building The Salk Institute, defined concrete as a liquid stone or a hollow stone. A material that takes over all constitutive qualities of a stone - hardness/firmness, texture, poetics, symbolism and mythology.

Nowadays, a lot of architects still think of concrete as "a contemporary stone", "a matter without the defects of stone". Concrete is still a means of conveying various architectural ideas and is a quintessence of materiality - it is a material whose secret is revealed in technical and technological knowledge, in a "mystery" discovered by a logical and scientific act. For an architect, concrete becomes an end in itself - he creates concrete in his imagination, from the need to show the form and meaning of its physical and aesthetic qualities. The choice of material goes hand in hand with the choice of technique. Formwork appears as a matrix for a form that acts as a "positive" of an architect's imagination. What is more, concrete is "loaded" not only with energy, laws or potential, but also with diverse ways of artistic and pre-artistic creation.

Nevertheless, concrete as a building material does not exist independently. Frank Lloyd Wright called concrete a stone created in form. Therefore, concrete is a form of formwork - a form assumed in the mind of a creator, which gives architecture its aesthetic and technical sense. Cyrille Simonnet describes concrete as a state of matter without an original image [1, pp. 55-75], which among other materials - due to its "liquid" nature - has no model, no original form that could be demonstrated through reproduction/copying. Produced as the result of a chemical, technical or aesthetic thought, concrete and reinforced concrete are always related to the state whose definition and image never seem to be completed and closed.

Due to its potential for transformation, concrete seems to be the "matrix" of architectural ideas - concrete is a material trace "prone to imagining" and an imprint of formal expressions. As an unbound, composite matter (a mixture of aggregate, water and cement), concrete is - to a certain extent - a synonym to Aristotle's "prime matter", which could be treated as a metaphysical substrate of changes in architecture. Primarily, concrete is only a name, a quality which has the ability of taking shapes - it is a universal body. As a ready substance, frozen in 
form, concrete becomes a "secondary matter" - a material whose physical qualities become a building material for an idea/metaphor defined by a creator. These two categories of matter are the proper subject of an architect's work - as a physical object, as a "substrate" - a basis for any architectural forms, but also as an "abstract" - showing its qualities and meanings given by an architect.

In both states of aggregation, concrete "gains the privilege" of becoming a metaphor - a transgression of qualities creating new, unique meanings of architecture. Concrete, together with its "elusive" nature, becomes rather an element than a body or substance, in the same sense as fire, water, air and earth. Louis Kahn emphasised this aspect of concrete by appealing to the common sense and intuition of architects: "You must know the nature of concrete, that what it really wants to be. Concrete wants to be granite, but it will never become it. Iron rods might act as a secret creator enabling this so-called liquid stone to appear as a splendid creation of the human mind. [...] That is what concrete wants to be: a product of a mind" [2, pp. 26-33].

Concrete architecture is an example of creation, where a creator makes ideal and formal decisions based on a priori chosen building material. Concrete architecture is a discipline where everything designed by a creator is totally submitted to concrete. Similarly to a sculptor, whose work totally depends on matter, an architect first looks for a material, and only then decides about the shape "hidden" in the material. Unlike steel, brick or wood, concrete is ideally predestined to this role because concrete itself is a matter in statu nascendi, gaining sense and changing meanings with the change of an ideal or formal context. This aesthetic "effectiveness" of concrete is a quality subordinated to the creator's will to show some general content where concrete acts as a fundament, as well as more detailed solutions where concrete conveys the essence of its usage.

\section{Detail}

For the last one hundred years, a concrete detail has been this place where architects building from concrete have tried to find a specific "nature" of concrete buildings. It does not matter what we are looking at - a modern, post-modern or deconstructionist building - an architectural detail seems to have the same potential as the whole structure/building. In the search for formal models of architecture, we reach the moment when we begin to understand that a concrete detail also has its model references - hidden in fully conscious and determined acts of an architect. This analogical rule can be seen in "stark, concrete" buildings by August Perret and Le Corbusier, in decorative stylistics of Carlo Scarpa or in Louis Kahn's detail "finding order". Each of them created different basis for the understanding and logic of the architectural detail - regardless of the fact if it is an autonomic part of architecture or it is treated as its completion.

Although stylistic aspirations vary, the clarity and ideal honesty seem to be the same for all of them. Perret looked to the past, to a classic gothic cathedral. For Le Corbusier, his vision of an ideal detail was, at the same time, thinking from general to detail and from detail to general and the balance between those two poles of architecture. After years of technical solutions, Le Corbusier's "narrative detail" [detail parlant] inspired by an orphic motif (mainly male- 
female) was transformed into the principle of architectural image/picture hidden in a detail reproducing the unity of an idea and a material. For Carlo Scarpa, a detail is this category of architecture that derives from individual beauty - "a beautiful detail" or "beautiful parts", which connected into a whole become ideal beauty.

According to Louis Kahn, the detail is the very beginning of any architecture - "if you deal with a fragment, regardless its size, structure, light, you react to its character, its spiritual atmosphere. We notice that everything proposed and realised by a man becomes an individual being" [3, p. 69]. Kenneth Frampton shares this opinion. He treats detail as an essential part of a joint that gives a relevant, narrative meaning to every structure through the visibility and quality of the joints: "Constructing and interpreting architecture happens in a joint, in a fertile detail. [...] The original Indo-European core of the word art means joint" [4, p. 18]. The principle of transgression and joint does not only reflect a system of building, but it also "designates" joint connections for the whole structure. This type of thinking results in discussions about what once was called an ornament and now is called an architectonic detail.

Nowadays, in Poland, there are a few architects who follow the abovementioned. They associate perfection of architecture with something, which we define as the search for aesthetics in an adequate expression of forms. For some of them, due to its qualities, concrete becomes a thing that belongs to the world beyond architecture - in keeping Le Corbusier's thesis that "architecture is a plastic problem". This poetic transformation of concrete into an image becomes an inherent attribute of expressive metaphorics. For others, architecture is an opportunity to demonstrate/show order through a building material - simple and honest in its message - corresponding to Le Corbusier's symbol of "an open hand". For them, concrete becomes the tool for creating a rational space supported by a reduction of means of expression.

Does concrete in recent Polish architecture have these two different faces? It seems that both stylistics of concrete architecture are clear and create in their own ways a coherent world filled with architects' convictions about the perfection of the used material. Also, both ways of presentation - metaphoric and rational - should not be treated as opposition, but as a competition for contemporary forms. A detail of concrete architecture creates new typologies and emphasises its own unique style.

\section{Looking for expression - metaphors in concrete}

In architecture, the image of reality has always seemed "insufficient" and it might be the reason for creating metaphoric architecture that has "compensating" functions. Once, it is a belief in a poetic need to use the power of metaphor to enhance the formal expression of a building. Another time, it is the awareness of architecture as publicly received art, which is the reason of introducing architecture into the world of unusual communication with a viewer through the language of fiction - things emphasising freedom of expression against normalised reality. This poetic interpretation of architecture as the art of creating "new" is a metaphoric image - it gains its own individual value and a proper semantic status. 


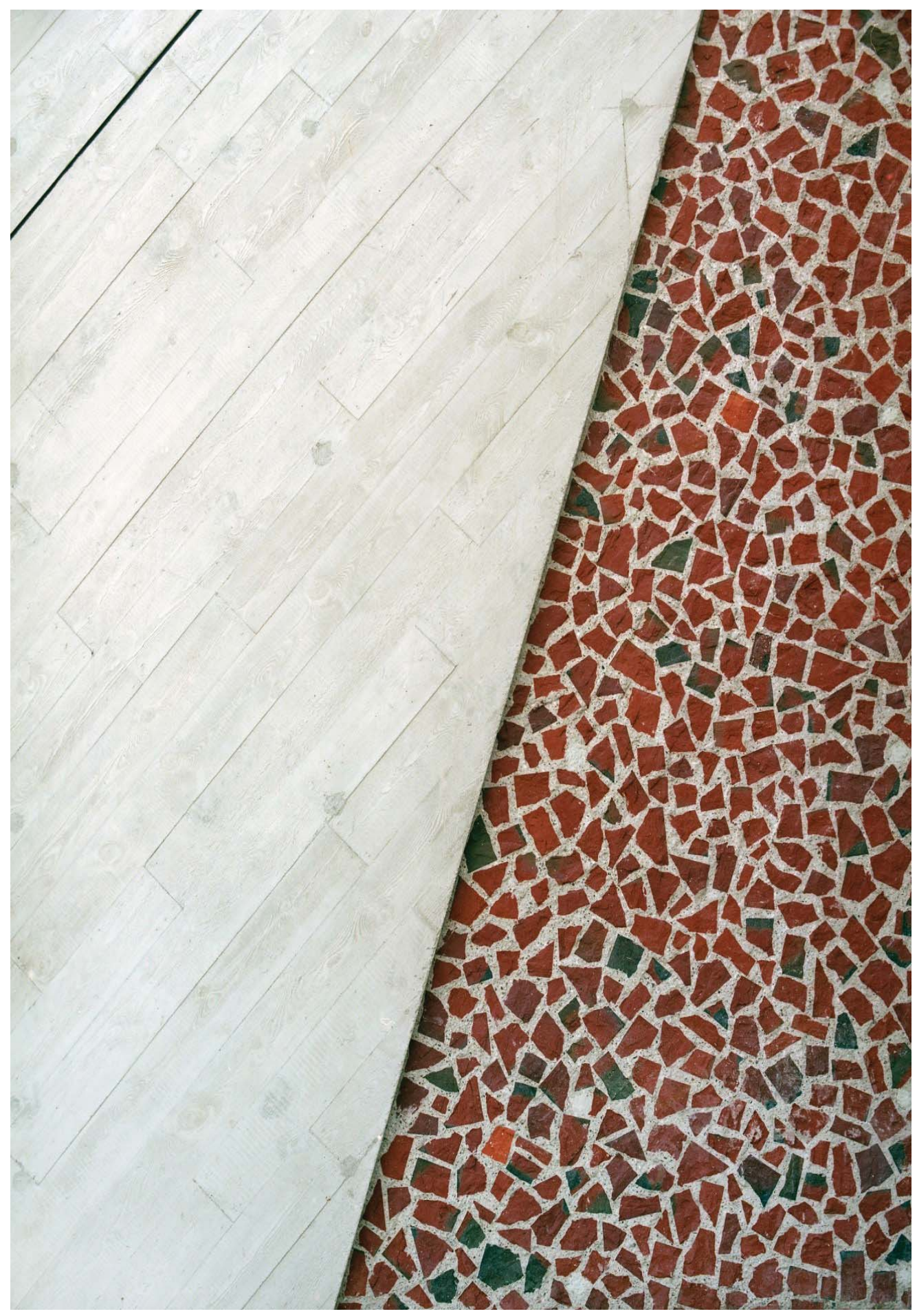

Fig. 1. F. Menis, Jordanki Cultural Congress Centre in Torun (2015). Detail of picado 
The constant emphasis of isotopic qualities of concrete is characteristic for Fernando Menis. Jordanki Cultural Congress Centre in Torun (2015; Fig. 1) and is an example of looking for such stone qualities of concrete, which would be adequate to reinterpret architecture as a thing based on the archetype of the cave (also the grave, shelter, bunker, bastion). The cave is a principle of creating a stereotomic space - mass subtracted in matter, connected with earth or rock - it introduces us to the world of mass, darkness, emptiness and mystery, separation from the outside world. It is stability and connection with the basis. Menis likes stark architectural forms relating to the shapes of nature. He mainly uses concrete, wood and stone juxtaposing their colours and textures and bringing out the qualities of their structure by the play of light and shade.

In the monumental Torun building, a detail attained a very specific identification. From the outside, the block is made from light concrete with a visible sketch of wooden boarding divided into diagonal squares, which introduce a sense of dynamism that emphasises a strong organic form. Carvings, overhangs and shelves in intensive colours attract our attention. Picado, which is concrete mixed with brick, is a conscious reference to the historic brick buildings of Torun. This interesting conglomeration of concrete and aggregate highlights the dichotomy between heritage and modernity in the cultural centre. Inside the building, the sculpted surface of the concert hall is accompanied by rooms that remind labyrinths and flexibly connect various functions. In Jordanki Centre, concrete through its monolithic representation fulfils the sense of topophilia - the subjective and emotional reception of the place and its material character.

In the concert hall, picado gains a new additional meaning. Apart from plastic effects, concrete is a matter that absorbs sounds. Due to the use of mobile ceilings and other technically advanced solutions, picado has excellent acoustics and acts as an absorber during symphonic concerts and opera performances. All in all, the mixture used by the architect gave the building a mimetic character in relation to the historic centre of Torun. What is more, it also got a function of solid protection/wall separating this space from the surrounding noise of the city. Three independent concrete volumes determine darkness and silence of the space where the simplicity and starkness of the material are accompanied by light going through the cuts in porous cubatures. Together with the lighting, concrete refers to the walls of Plato's cave, which reflect the unreality of the real world. Shattered and diffused light creates fantastical patterns and figures. Their interpretation depends on the perspective, knowledge and sensitivity of the viewer. The understanding of this idea depends on the shape of an image projected "onto" the matter and transformed "into" matter. And if it is true that "the sensual world is older than the rational world" [5, p. 205], the astonishment towards matter and lit spatial shapes ordered in matter is an excuse to discover the architecture of Fernando Menis. The metaphor of such building reveals a real fundamental base for this part of architecture where searching for sense consists in finding material meanings.

We can see a similar role of concrete - relevant for transforming the concept of a concert hall into a real image of architecture - in the building designed by Konior Studio for The National Symphonic Orchestra of The Polish Radio in Katowice (2014; Fig. 2). The concert hall was treated as a monolithic "vessel for sounds". The metaphor of a vessel is an 


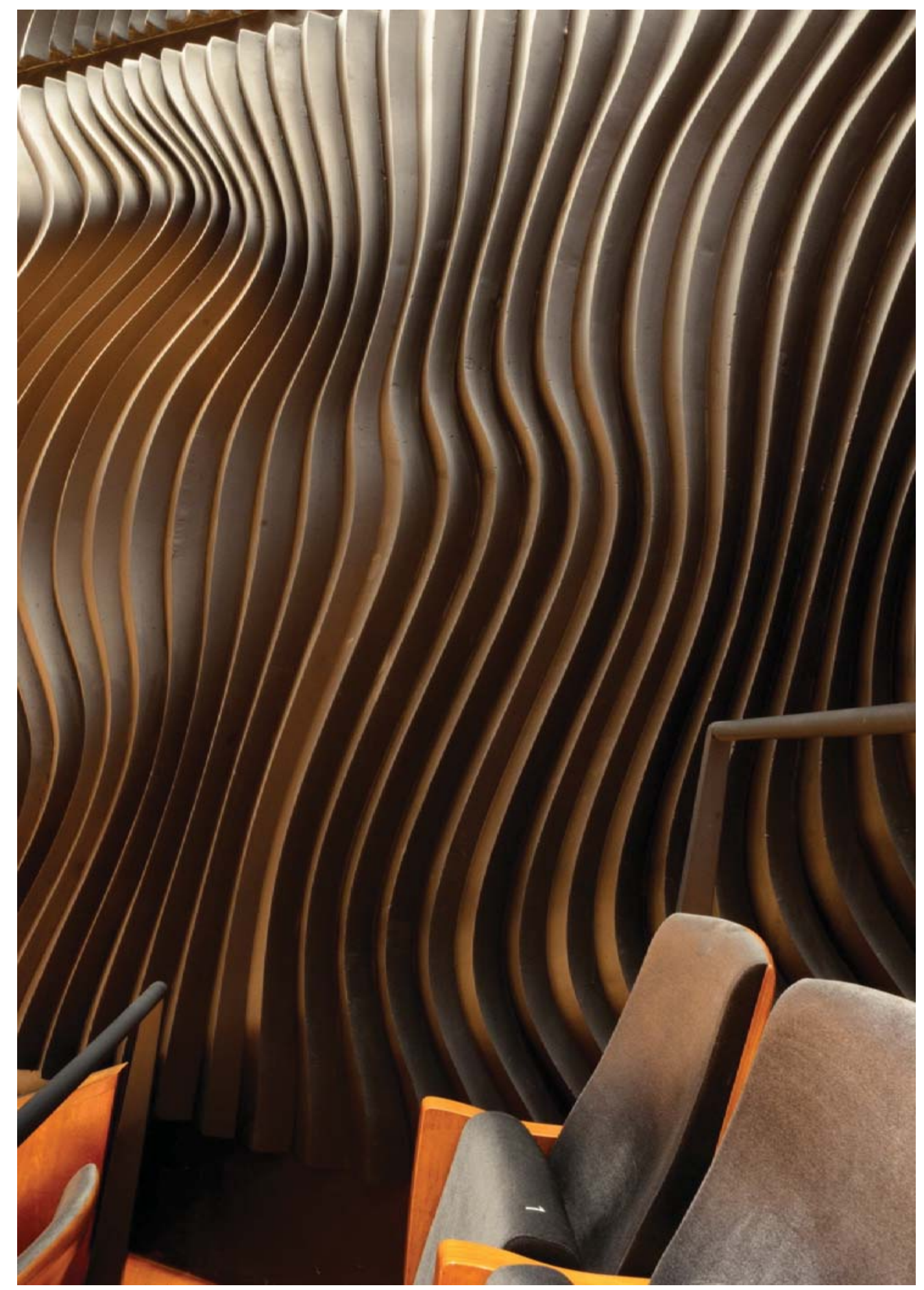

Fig. 2. Konior Studio, The National Symphonic Orchestra of The Polish Radio in Katowice, 2014. Wall of Concert Hall

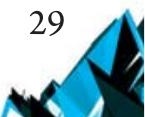


excellent depiction of adequate formation in adequate matter in order to transfer this or another imagined content. Form, content and material should become one, they should complete each other. The way of designing and building NSOPR reveals a creative sensuality, a perception and reception of form and selecting adequate materials - they also prove the architect's praise of patience in creating detail. The NSOPR building is the praise of a specific process of forming a building. Systematic buildings from concrete and brick, together with the sensitivity to light, touch, hearing, come from a deep belief that architecture is a certain "slowness" of acting, aspiring to perfection, but also - eventually - a feeling of immaterial aura created by material objects. In such approach, we can recognise a reference to Louis Kahn's statement that a building must begin with the immeasurable, it must go through being designed and built in order to re - present its immateriality. When we look at the NSOPR building, we should appreciate a visible care about the quality of each element - it might be the texture of the anthracite overhang bearing the traces of boarding in the foyer, intricately impressed relieves on the walls of the main concert hall or the hand-baked facade brick. The architect was able to turn concrete matter into a form that emphasises the weight and density of "liquid stone" and shows its plastic and liquid potential - the space transforms from a hefty, impervious concert hall into a sophisticated play of concrete wall folds. Each detail completes the form to create a sense of Gesamtkunstwerk, where form should be interpreted as a structure of space and matter, regardless of being represented in equilibrium of blocks or the alternation of light and shade. In Tomasz Konior's version of architecture, there are two equally important aspects: the understanding of concrete matter and the determination to transform "a usual object" into "a unique object".

Another model example showing the connection between the city's physiognomy and the contemporary concrete architecture is The Museum of The Second World War in Gdańsk (2016; Fig. 3), designed by the local Studio Kwadrat. The characteristic red building with a dominant 40-metre high tower is situated on the bank of Radunia. The building is not only a mere symbol of the city; not only does it include connotations with the silhouette of Gdańsk Old Town, but it also defines a certain range of comparisons. In its open to interpretation shape, the museum follows the tradition of creating contemporary architectonic forms that should express, not only represent. The expressionist design of the building refers to the specific historic and political values avoiding symbolic solutions. A decomposed form, together with its sophisticated geometry, seems to be a manifesto for discussing the Second World War. According to the designers, it is supposed to be "a universal sign", a tribute to the successful attempt of translating the stability of matter into "the energy of form". The building, which looks like a leaning prism, might bring associations with a missile or a house damaged during a war. The abstract form does not imitate any known shapes. Therefore, instead of simple reproduction, it creates a disturbing atmosphere of the place. Some see it as a sinking ship, some compare it to a crumbling building while others see it as a rocket half-buried in the ground, a dam, an obstacle or a grave candle.

The main material of the building - monolithic concrete, is invisible to the viewer. It is covered with irregularly put facing from red torkrete and facade glass. Yet it is concrete that is responsible for creating "a wobbly" space whose material coherence allows to interpret the multi-layered shape and superior spatial logic. Inside, the homogeneity of red planes gives place to a homogeneous 
stark monolith completed with anthracite panels, exposed installations and simple wooden furniture. All of it gives us the specific meaning of war monuments - shelters, bunkers, redoubts. By creating a whole, concrete announces the eccentricity of the building-sculpture and the designers' uncompromising approach to form - the function of the building seems secondary.

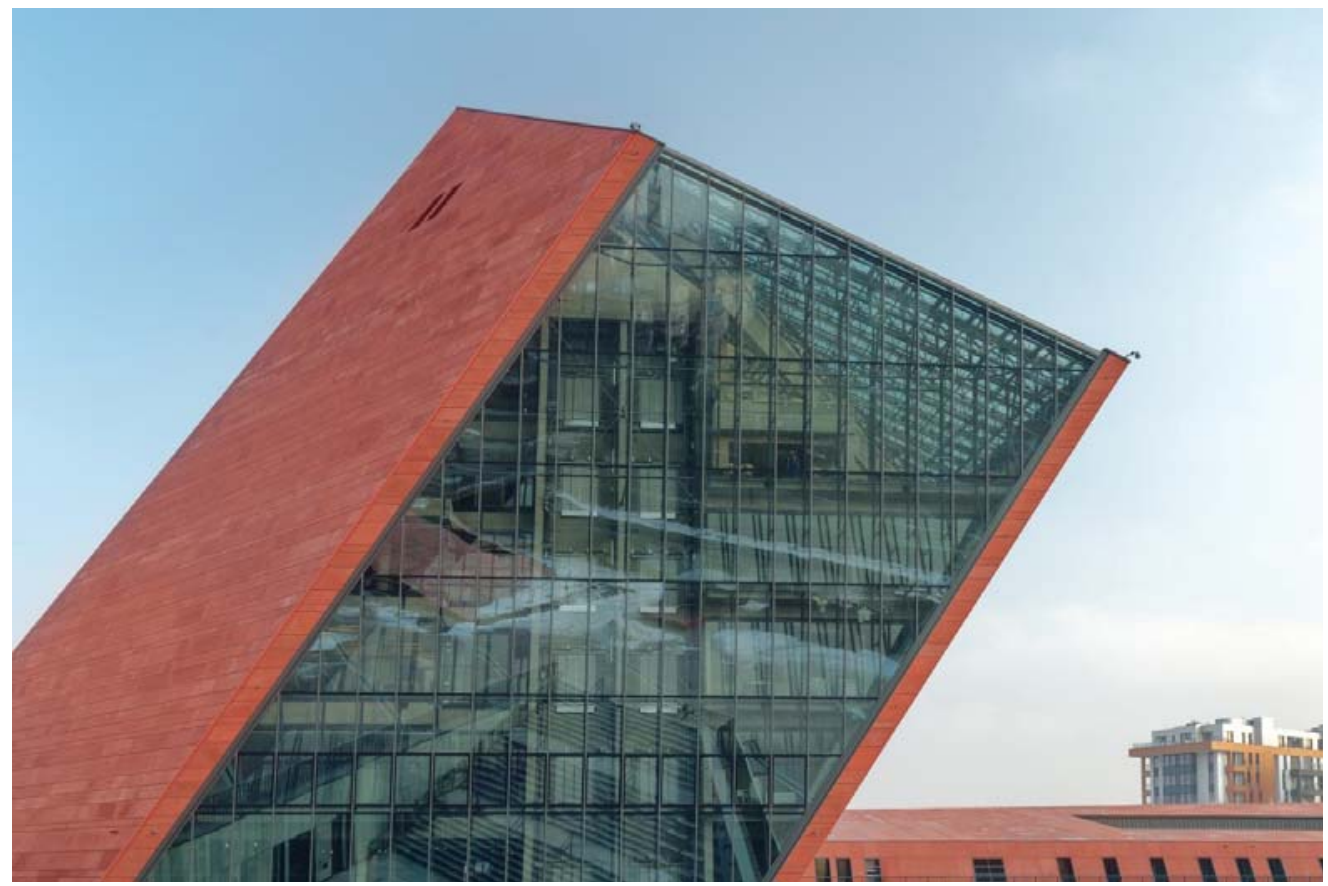

Fig. 3. Kwadrat Studio, The Museum of The Second World War in Gdańsk, 2014

Aerotunnel in Mory near Warsaw (2014; Fig. 4), designed by Lewicki and Latak Studio, also has theoretical references. This unusually shaped tower is a place where you can learn parachute jumping and experience the sheer joy of being torn from the ground. According to the designers, the unusual shape was inspired by a plastic bag filled with air. The bag takes on irregular and unpredictable shapes. A bag, a kite, a sleeve, a paper balloon are forms we always associate with first attempts of taking off, flying and counteracting gravity. A very special problem in the case of this object was the right choice of material. After all, the designers' ambition was to show the struggle between wind and gravity. At first, they thought of a technical fabric, but finally they decided on reinforced concrete. Reinforced concrete allowed them to introduce additional functions. It also allowed a stable wind flow. This expressive form (very closely resembling The Einstein Observatory in Potsdam, by Erich Mendelsohn, 1921) has the features of an interesting deconstruction. For a modern architect, a function is not the only reason to create, the reason to create is rather a concept supported by imagination. The aim of imagination is to find the most original shape for a building in a chosen material. The world of dynamic and radically decomposed architecture tells us that architecture cannot survive without concrete. Even the most extreme independence of form 
assumes an adequate matter in which the form will be revealed. In the Aerotunnel, naturally cast concrete in a system formwork becomes a dynamic material supporting the sense of shape "frozen in one pose" and creating a kaleidoscopic play of light, shade, asymmetry as well as the imagination of the designers.

The building of The Museum of Polish Aviation in Kraków (2010; Fig. 5) required a specific approach to concrete (designed by Pysall. Ruge Architekten and Bartłomiej Kisielewski). The building attracts attention due to a careful layout clearly associated with the function of the museum and the presented exhibits. The basis for the museum shape is a modification of a basic module, which looks like a cut and folded (like origami) square sheet of paper resembling in its layout a triangular propeller. Based on a concrete platform, massive cement pliability/litheness and ubiquitous "supremacy" of concrete planes recreate a certain sense in interpreting form for function. The aspect of freedom of composition seems to follow ideas shared by Oscar Niemeyer, Eero Saarinen, Frank Gehry and Zaha Hadid. It manifests the sense of an architectural sculpture to show other sculptures/exhibits; to create a work of art for other works of art. Thanks to them, we know that a curved line, a curved plane, an arched substring are natural shapes of architecture. The aesthetic values of a building can be expressed only through idiopathic components.

This sophisticated metaphor rejecting a right angle and its unhindered geometry is accompanied by a visible care about each concrete, steel or glass detail. The curves of the outside 120-centimetre shell made from dyed anthracite concrete required special solutions and profiled lost formwork put on a steel substructure. The repetitive trace of impressed formwork tops, the finishing touch of corners, windows, the interior of museum rooms and offices, or the final polishing of facades prove that the detail separated from the fundament of modernist myth becomes an important freed from low quality element - it depends on the vision, sensitivity and knowledge of those who re-create it again and again.

The Museum of Martyrdom of Polish Country Folk (designed by Nizio Design International, 2017; Fig. 6) in Michniów belongs to another category of deconstructed concrete metaphors. It commemorates the tragic pacification of the village by the Nazis in July 1943. The architecture of the building is connected with recognisable archetypes of: The House, the Way, the Gate, the Border, the Garden, the Tree. Some of these elements are repetitive and recognisable - other create the world subordinated to the materialisation of ideas through preservation in the material. Together, all of them create the model where light, water, building material are as important as its specific formal shape.

The design of the museum is a consistent continuation of the concept aiming to show the disintegration and deformation of a traditional country house. The linear monumental figure emphasises the unity of historic and architectonic narration. Its main sense is the monolith of concrete. The road you have to follow through cement walls tells us about the tragic events. It also builds additional narration. Starting from the full figure of the "House" (serving as a chapel), through individual scattered parts of the exposition, eventually we reach the place that determines the final disappearance and destruction. Light shining through windows and skylights in an 80-centimeter outside wall is an essential element of this symbolic road. The stripes of light, together with inner facades, create a consistent composition of lines, 


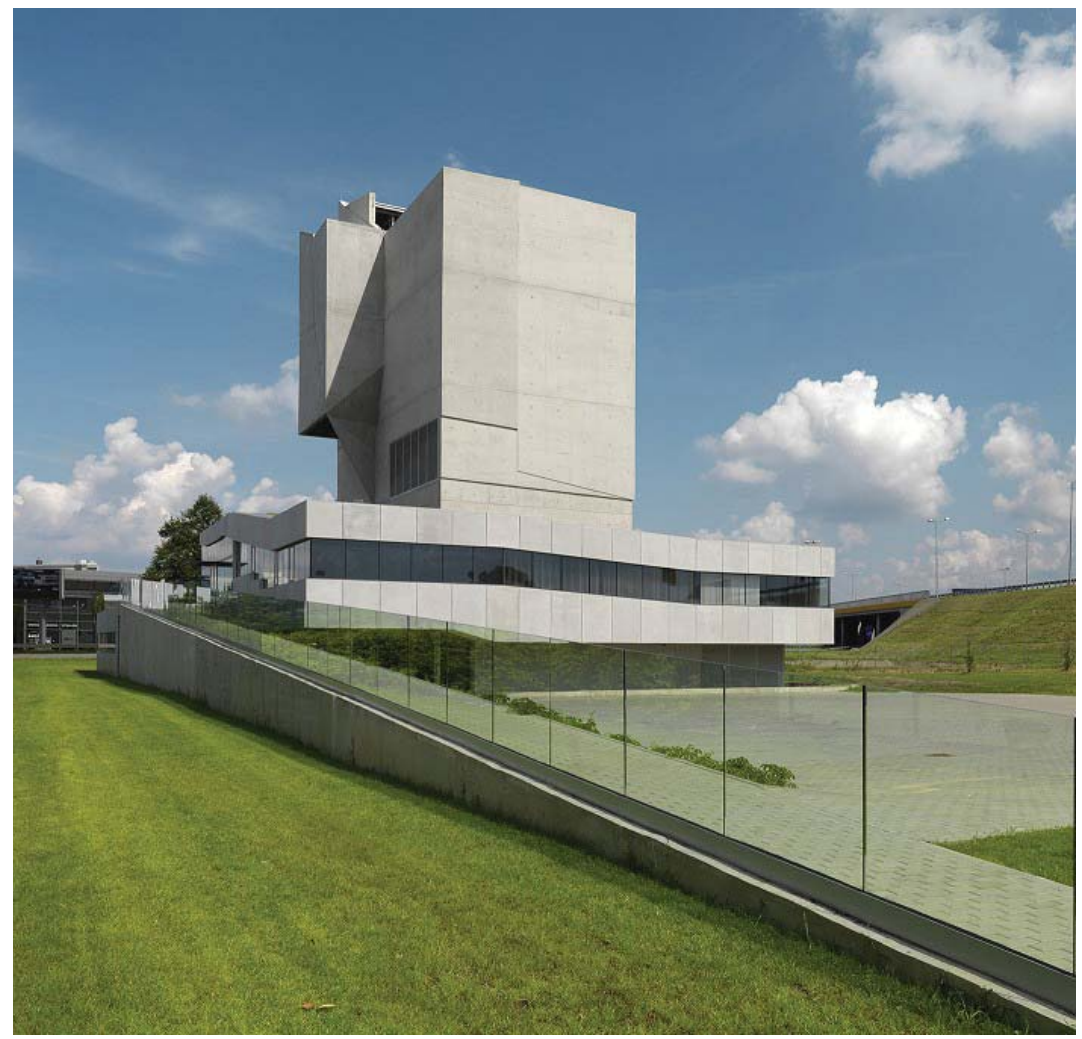

Fig. 4. Lewicki and Latak Studio, Aerotunnel in Mory, 2014

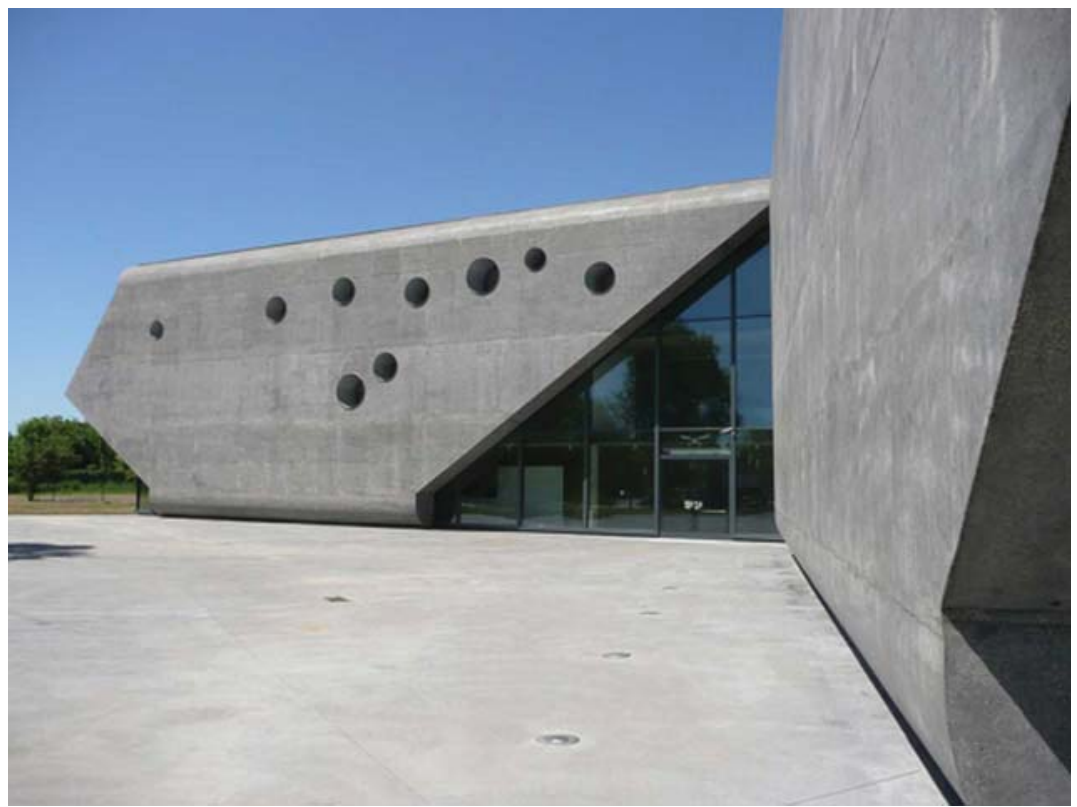

Fig. 5. Pysall. Ruge Architekten and Bartłomiej Kisielewski, The Museum of Polish Aviation in Kraków, 2010

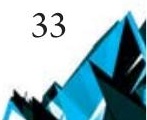


cuts and rays adequate for the object that should transform profane matter in sacred space commemorating the tragedy of the people from Michniów.

The symbolism of "non-presence", through a "naked" and impersonal form frozen in concrete, becomes a fundamental image after a non-existing object. By using the essential, wellknown metaphor of the house, the designers create the universal sign of disintegration, death and passing based on the dualism of something that is present and non-present at the same time. Concrete "houses" in Michniów seem to visualise a "post mortem mask of architecture".

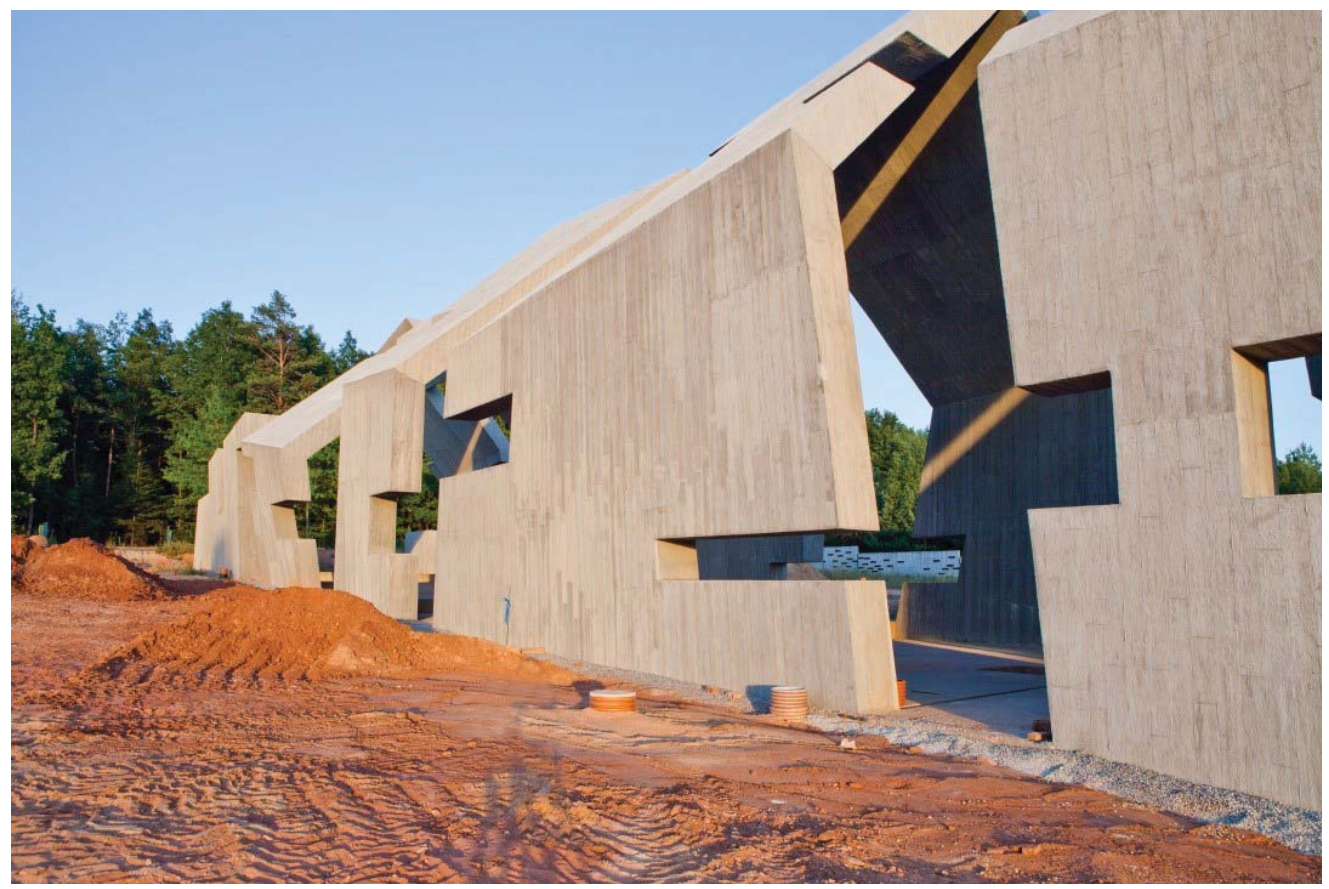

Fig. 6. Nizio Design, The Museum of Martyrdom of Polish Country Folk, Michniów 2017

\section{References}

[1] Simonnet C., Le Béton en représentation - La Mémoire photographique de l'entreprise Hennebique 1890-1930, Paris 1993, 55-75.

[2] McCarter R., Louis Kahn and Nature of Concrete, "Concrete International" (32) 12, Farmington Hills 2009, 26-33.

[3] Brownlee D.B., Carnet du visiteur: Louis I. Kahn, le monde de l'architecte, Paris 1992.

[4] Frampton K., Rappel à l'ordre; Gtos w sprawie tektoniki, Czasopismo Techniczne, 14-A/2011.

[5] Merleau-Ponty M., Oko i umyst. Szkice o malarstwie, Gdańsk 1996. 